\title{
Research on the Influence of the Characteristics of Independent Director to the Quality of Internal Control Self-Assessment Report
}

\author{
Weiwei Huang \\ Management School, Jinan University, Guangzhou, China \\ Email: 449104406@qq.com
}

Received 19 May 2015; accepted 9 June 2015; published 15 June 2015

Copyright (C) 2015 by author and Scientific Research Publishing Inc.

This work is licensed under the Creative Commons Attribution International License (CC BY). http://creativecommons.org/licenses/by/4.0/

(c) (i) Open Access

\begin{abstract}
This article selects the empirical data from Shanghai A share, using multiple linear regression model to discuss the impact to the quality of the internal control self-assessment report from four aspects of the characteristic of the independent directors. The conclusions are that the number of independent directors, the independent directors' proportion and the auditing professional background of independent directors are positively correlated with the quality of internal control self-assessment report, and the age of the independent directors, the independent directors' reward and the location consistency of the independent directors and the company are negatively correlated with the quality of internal control self-assessment report. Finally, this paper gives four suggestions.
\end{abstract}

\section{Keywords}

Characteristic of Independent Director, The Quality of Internal Control Self-Assessment Report

\section{Introduction}

In the process of internal control information disclosure, independent board plays a certain role. Simon and Kar [1] found that if the company sets up internal audit committee, the companies are more willing to relevant information disclosure. However, if the number of family members on the board is large, the company voluntary information disclosure level will diminish. This proves that the worse the independence of the board of directors, the less the voluntary disclosure of information.

Eng and Mak [2] studied 158 listed companies in Singapore and discussed the impact of company characteris- 
tics to internal control disclosure of information. Among them, the company features include the following aspects: size of the company, debt ratio, ownership structure, proportion of outside directors, shareholding ratio of the structure of the board of directors, government share holding ratio, and managers' shareholding ratio. They get the following conclusions: the proportion of outside directors, board structure and ownership structure is obviously associated with internal control disclosure of information; if the shares proportion that government holds is large and the proportion of shares that company executives hold is low, the internal control information disclosure will be improved; and large companies and low debt ratio can increase the disclosure of information.

This article selects the empirical data from Shanghai A share from 2011 to 2013, using the multiple linear regression model to measure the impact to the quality of the internal control self-assessment report from four aspects of the characteristic of the independent directors.

\section{The Theoretical Analysis}

\subsection{The Principal-Agent Theory}

The principal-agent theory encourages separating ownership and management that the owners of the company give the right of management to operators, and they only keep residual claims. Therefore, operators have the important responsibilities to protect assets and complete enterprise assets value-added tasks. Although the existence of principal-agent relationship can solve the problem that owners cannot develop as a result of the limitation of professional ability, but it also brings a lot of problems behind this. If the system in the enterprise is invalid, the agent is likely to use the advantages of information they have to maximize their own interests, which will damage the interests of the principal. As a result, the principal will try every way to supervise the agent. The disclosure of the internal control self-assessment report can moderate conflict that the principal-agent relationship brought [3]-[7].

\subsection{The Theory of Internal Control}

COSO [3] refers that the internal control should be implemented by the board of directors, managers and other employees, which can improve the effect and efficiency of business activities, and enhance the reliability of financial statements and assure the compliance of relevant laws and regulations. The independent director system is an important system arrangement of the internal control, and independent directors as an effective supervision mechanism, can impact on enterprise's internal control-self assessment report. If there are independent directors in the company, it can provide reasonable assurance of the completeness of the accurate internal control selfassessment report [8]-[11].

\section{Hypothesis of This Paper}

In order to make sure the company can survive in the fierce competition in the market, senior managers need to have the exquisite adept management method, accurate investment horizon, excellent communication and coordination ability and professional competence including the accounting, law and other related professional knowledge. If the independent directors is young, lacking of experience and precious practical experience, then when doing related decisions, they may make inappropriate decisions, which will affect the quality of the internal control self-assessment report [12] [13]. With the increase of age, the independent directors of rich experience, has a better understanding on the internal control, which can better improve the quality of the internal control self assessment report. As a result, the first hypothesis is proposed in this paper.

Hypothesis 1: If the independent director is older, the quality of internal control self-assessment report of the listed company is higher.

In fact, except for the independent director's own reputation which would help them work dutifully in the listed company, the reward they receive can also make them work hard [14] [15]. Because independent directors usually have their own jobs outside company and they are not In charge of daily management, their time is valuable when providing services [16] [17]. Meanwhile, it may be risky for independent directors providing useful advices which based on their rich management experience and professional knowledge. Due to using wrong policies, independent directors must bear losses and face pressure from the company's shareholders and other stakeholders. So it is necessary to improve the independent director's reward to encourage them to provide higher-quality services. Above all, we put forward our fourth hypothesis. 
Hypothesis 2: The higher the independent director's reward is, the quality of the listed company’s internal control self-assessment report is higher.

In real life, due to geographical distance, time limit, the independent director cannot attend the board of directors on time or cannot attend the board of directors, this will impede independent directors to exercise their rights to the major matters and make objective and fair evaluation of enterprise, influence the "external" supervisory function of the independent director for the enterprise [18] [19]. If the negative factors decrease, the independent directors will be more willing to attend the board meeting, the number of independent directors to attend the board meeting will be increased, so the independent directors have further understanding of the situation of the company and follow up, they also can make more reasonable and objective evaluation and decision making, provide more supervision. In addition, if the independent directors and listed companies are in the same region, independent directors can more quickly and easily collect information on the enterprise, reduce the time and economic costs, in line with the economic benefit. What's more, independent director is more likely to win first-hand information with higher credibility, which can effectively supervise on the listed companies.

Hypothesis 3: If the independent directors and listed companies are in the same place, the quality of the Internal control self assessment report of the company is higher.

\section{Data and Methodology}

\subsection{Model}

In this paper, the explained variables are the age of the independent directors, the reward of the independent directors, the location consistency of the independent directors and the company, and the dependent variable is the internal control information disclosure index (ICDI). There are control variables of eight factors in the company, including industry characteristics, the asset scale, capital structure, profitability, the joining together of two position, the nature of first big shareholders, the proportion the first big shareholders holding and the time variable. As a result, the multiple linear regression model is established in this paper [20].

$\mathrm{ICDI}=\alpha+\beta_{1} \mathrm{AGE}+\beta_{2} \mathrm{PAY}+\beta_{3} \mathrm{PLACE}+\beta_{4} \mathrm{IND} 2+\beta_{5} \mathrm{IND} 3+\beta_{6} \mathrm{IND} 4+\beta_{7} \mathrm{IND} 5+\beta_{8} \mathrm{SIZE}+\beta_{9} \mathrm{LEV}+$ $\beta_{10} \mathrm{ROA}+\beta_{11} \mathrm{CEO}+\beta_{12} \mathrm{SHAREC}+\beta_{13} \mathrm{SHARE} 1+\beta_{14} \mathrm{YEAR} 2012+\beta_{15}$ YEAR2013 $+\varepsilon$

\subsection{Instructions of Variables}

ICDI is a percentage value, it gets scores from four aspects of the internal control self-assessment report, and the sum scores finally is divided by total score of 80 points. The internal control self-assessment is scored according Table 1.

Age is the average age of the independent directors in the listed company.

PAY is the logarithmic average total reward of independent directors.

PLACE is a dummy. Only if the location of the independent directors is consisted with the location of the company, its value is 1 , other with 0 .

IND2 is a dummy. Only if the industry is real estate industry, its value is 1 , other with 0.

IND3 is a dummy. Only if the industry is comprehensive industry, its value is 1 , other with 0 .

IND4 is a dummy. Only if the industry is industrial, its value is 1 , other with 0 .

IND5 is a dummy. Only if the industry is commerce industry, its value is 1 , other with 0 .

SIZE is the exponential value of the enterprise total assets at the end of last year.

LEV is asset-liability ratio, that is the value of total liabilities divided by total assets.

CEO is a dummy. Only if the chairman is also a general manager, its value is 1 , other with 0 .

SHAREC is a dummy. Only if the nature of the largest shareholder is state-owned shares, its value is 1 , other with 0 .

SHARE1 is the stake of the largest shareholder.

YEAR2012 is a dummy. Only if the year is 2012, its value is 1 , other with 0 .

YEAR2013 is a dummy. Only if the year is 2013, its value is 1, other with 0.

\subsection{Data Source}

The article selects Shanghai A-share companies in 2011 to 2013 as the research sample, choose the annual internal 
Table 1. Assignment rules table.

\begin{tabular}{|c|c|}
\hline Content & Assignment instructions \\
\hline The authenticity of the statement of the board of directors to report & State $=5$, Non State $=1$ \\
\hline $\begin{array}{l}\text { Whether to disclose the certified public accountants audit } \\
\text { opinion of internal control }\end{array}$ & Disclosure $=5$, Non Disclousure $=1$ \\
\hline The identifications of internal control defects & $\begin{array}{l}\text { Disclosure of Qualitative and Quantitative }=5 \text {, } \\
\text { Disclosure of Qualitative or Quantitative }=3 \text {, Non Disclosure }=1\end{array}$ \\
\hline Disclosure of internal control defects & Detailed Disclose $=5$, Simple Disclosure $=3$, Non Disclosure $=1$ \\
\hline Conclusion of effectiveness of internal control & Detailed Disclose $=5$, Simple Disclosure $=3$, Non Disclosure $=1$ \\
\hline The improvement plan of internal control & Detailed Disclose $=5$, Simple Disclosure $=3$, Non Disclosure $=1$ \\
\hline The overall summary of internal control & Disclosure $=5$, Non Disclousure $=1$ \\
\hline The scope of internal control evaluation & Disclosure $=5$, Non Disclousure $=1$ \\
\hline The internal control evaluation program & Disclosure $=5$, Non Disclousure $=1$ \\
\hline Internal control evaluation method & Disclosure $=5$, Non Disclousure $=1$ \\
\hline The Basis of internal control evaluation & Disclosure $=5$, Non Disclousure $=1$ \\
\hline The internal control environment & Detailed Disclose $=5$, Simple Disclosure $=3$, Non Disclosure $=1$ \\
\hline The risk assessment & Detailed Disclose $=5$, Simple Disclosure $=3$, Non Disclosure $=1$ \\
\hline Control activities & Detailed Disclose $=5$, Simple Disclosure $=3$, Non Disclosure $=1$ \\
\hline Information and communication & Detailed Disclose $=5$, Simple Disclosure $=3$, Non Disclosure $=1$ \\
\hline Internal supervision & Detailed Disclose $=5$, Simple Disclosure $=3$, Non Disclosure $=1$ \\
\hline
\end{tabular}

control self-assessment report one year as the research object, eliminating missing data, in total there are 1647 observations. All the data is from CSMAR database and the prospectus of the company, processed through Microsoft Excel 2007 and STATA statistical software.

\section{Empirical Results}

\subsection{Descriptive Statistics}

According to Table 2, the average age of independent directors is 55, and the youngest independent director is 38 years old, and the oldest independent director is 74 years old. It shows that in most companies, there are many middle-aged independent directors who are full of experience. The average value of the pay of the independent directors is 4.761, it shows that the average reward of the independent directors is 57676 Yuan. The minimum value of the consistence of the location of the independent directors and the companies is 0 , and the maximum value is 1 , it shows that some independent directors' location is consistent with the company's location. The mean value of this index is 0.546 , it shows that more than half of the independent directors are in the same place with the company.

\subsection{Multiple Regression Results}

According to Table 3, we can know that the value of $R^{2}$ is 0.23 , and the adjusted value of $R^{2}$ is 0.21 , it shows that the model fits better. And the variables can explain $23 \%$ of the dependent variable quality of the internal control self-assessment report. Even though change the number of $\mathrm{R}^{2}$, the model can still explain $21 \%$ of the information. And the mean of the VIF is 1.24 , lower than 10 , it shows that there is no multicollinearity problem in this model.

\section{Conclusions}

In conclusion, if the independent director is older, the quality of internal control self-assessment report of the listed company is higher. 
Table 2. Descriptive statistics.

\begin{tabular}{|c|c|c|c|c|c|}
\hline Variables & Size & Mean & Std-error & Minimum & Maximum \\
\hline ICDI & 1647 & 0.661 & 0.152 & 0.3 & 1 \\
\hline AGE & 1647 & 54.66 & 5.763 & 38 & 73.67 \\
\hline PAY & 1647 & 4.761 & 0.229 & 3.574 & 5.9 \\
\hline PLACE & 1647 & 0.546 & 0.498 & 0 & 1 \\
\hline LEV & 1647 & 0.537 & 0.209 & 0.0473 & 3.930 \\
\hline ROA & 1647 & 0.0738 & 0.250 & -3.133 & 6.918 \\
\hline CEO & 1647 & 0.101 & 0.302 & 0 & 1 \\
\hline IND1 & 1647 & 0.155 & 0.362 & 0 & 1 \\
\hline IND2 & 1647 & 0.112 & 0.316 & 0 & 1 \\
\hline IND3 & 1647 & 0.0298 & 0.170 & 0 & 1 \\
\hline IND4 & 1647 & 0.616 & 0.486 & 0 & 1 \\
\hline IND5 & 1647 & 0.0868 & 0.282 & 0 & 1 \\
\hline SHARE1 & 1647 & 0.431 & 0.1643 & 0.2197 & 0.99 \\
\hline SHAREC & 1647 & 0.211 & 0.408 & 0 & 1 \\
\hline SIZE & 1647 & 9.883 & 0.612 & 7.645 & 12.37 \\
\hline
\end{tabular}

Table 3. The result of multiple regression.

\begin{tabular}{|c|c|c|c|}
\hline Variables & $\beta$ & The value of $t$ & VIF \\
\hline $\mathrm{AGE}$ & $0.00021^{* *}$ & $(0.38)$ & 1.140 \\
\hline PAY & -0.0133 & $(-0.92)$ & 1.210 \\
\hline PLACE & -0.00542 & $(-0.81)$ & 1.060 \\
\hline LEV & $0.0446^{* *}$ & $(2.81)$ & 1.210 \\
\hline ROA & 0.00633 & $(0.56)$ & 1.030 \\
\hline CEO & -0.0141 & $(-1.37)$ & 1.030 \\
\hline IND2 & 0.00403 & $(0.31)$ & 1.760 \\
\hline IND3 & 0.0185 & (0.99) & 1.200 \\
\hline IND4 & $0.0195^{*}$ & $(2.06)$ & 2.060 \\
\hline IND5 & 0.00504 & $(0.39)$ & 1.520 \\
\hline SHARE1 & 0.00764 & $(0.35)$ & 1.220 \\
\hline SHAREC & -0.00567 & $(-0.68)$ & 1.080 \\
\hline SIZE & 0.00178 & $(0.26)$ & 1.630 \\
\hline YEAR2012 & $0.131^{* * *}$ & (13.01) & 1.770 \\
\hline YEAR2013 & $-0.0407^{* * *}$ & $(-4.16)$ & 1.790 \\
\hline$\alpha$ & $0.634^{* * *}$ & $(8.08)$ & \\
\hline $\mathrm{R} 2$ & 0.23 & & \\
\hline adj.R2 & 0.21 & & \\
\hline $\mathrm{N}$ & 1647 & & \\
\hline Mean VIF & 1.24 & & \\
\hline
\end{tabular}


However, if the pay of independent directors is high, it doesn't mean that the quality of internal control self-assessment report of the listed company will be high. Because if the pay is very high, it will damage the independence of the independent director, which will affect the quality of the internal control self-assessment report. Besides, if the independent directors and listed companies are in the same place, it doesn't mean that the quality of internal control self-assessment report of the listed company will be high. As independent directors can get much information from all the aspects including the meeting, it won't take any effects even though the independent board can't attend the meeting because of the long distance.

\section{References}

[1] Ashbaugh, S., et al. (1996) Evaluating Internal Control Deficiencies. Economics, Management and Financial Markets, 4, 443-465.

[2] Beasley, M.S. (2009) An Empirical Analysis of Relation between Board of Director Composition and Financial Statement Fraud. The Accounting Review, 4, 129-133. http://www.jstor.org/stable/248566?seq=1\#page_scan_tab_contents

[3] COSO (1992) Internal Control-Integrated Framework. COSO, American.

[4] COSO (2004) Enterprise Risk Management-Integrated Framework. COSO, American.

[5] Daily, C. and Dalton, D. (1993) Board of Directors Leadership and Structure: Control and Performance Implications. Journal of Financial Economics, 1, 55-64.

[6] Duffy, M.N. (2004) Section 404 Opens a Door. Journal of Accountancy, 197, 55-64. https://www.questia.com/library/journal/1G1-118443312/section-404-opens-a-door-the-requirement-to-evaluate

[7] Eng, L. and Mak, Y. (2003) Corporate Governance and Voluntary Disclosure. Journal of Accounting and Public Policy, 22, 325-345. http://paduaresearch.cab.unipd.it/5180/ http://dx.doi.org/10.1016/S0278-4254(03)00037-1

[8] Eisenhardt, K. (1989) Agency theory: An Assessment and Review. Academy of Management Review, 14, 57-74. http://amr.aom.org/content/14/1/57.short

[9] Eng, L.L., Hong, K.F. and Ho, Y.K. (2011) The Relation between Financial Statement Disclosure and the Cost of Equity Capital of Singapore firms. Accounting Research Journal, 3, 288-307. http://papers.ssrn.com/sol3/papers.cfm?abstract_id=1609709

[10] Fama, E.F. and Jensen, M.C. (1983) Separation of Owner and Control. Journal of Law and Economics, 26, 301-325. https://wwz.unibas.ch/fileadmin/wwz/redaktion/Summer_School/2013/Yermack/Fama_Jensen_1983.pdf http://dx.doi.org/10.1086/467037

[11] Forker, J.J. (1992) Corporate Governance and Disclosure Quality. Accounting and Business Research, 22, $111-124$. http://en.cnki.com.cn/Article en/CJFDTOTAL-PZDG201102008.htm

[12] Hunton, J.E., Hoitash, R. and Thibodeau, J.C. (2011) The Relationship between Perceived Tone at the Top and Earnings Quality. Contemporary Accounting Research, 28, 1190-1224.

[13] Jenson, M.C. and Meckling, J.H. (1976) Theory of the Firm: Managerial Behavior, Agency Costs and Ownership Structure. Journal of Financial Economics, 3, 305-360. http://www.sciencedirect.com/science/article/pii/0304405X7690026X

[14] Bedard, J.C. and Johnstone, K.M. (2004) Earnings Manipulation Risk, Corporate Governance Risk, and Auditors' Planning and Pricing Decisions. The Accounting Review, 4, 227-304. http://dx.doi.org/10.2308/accr.2004.79.2.277 http://www.aaajournals.org/doi/abs/10.2308/accr.2004.79.2.277

[15] Meek, G.K., Roberts, C.B. and Gray, S.J. (1995) Factors Influencing Voluntary Annual Report Disclosure by US, UK and Continental European Multinational Corporations. Journal of International Business Studies, 3, 555-572.

http://www.jstor.org/stable/155561?seq=1\#page_scan_tab_contents http://dx.doi.org/10.1057/palgrave.jibs.8490186

[16] Park, Y.W. and Shin, H.H. (2004) Board Composition and Earnings Management in Canada. Journal of Corporate Finance, 10, 431-457. http://www.sciencedirect.com/science/article/pii/S0929119903000257 http://dx.doi.org/10.1016/s0929-1199(03)00025-7

[17] Perry, T. and Shivdasani, A. (2005) Do Boards Affect Performance? Evidence from Corporate Restructuring. Journal of Business, 8, 231-246. http://www.jstor.org/stable/10.1086/430864 http://dx.doi.org/10.1086/430864

[18] Ho, S.S. and Wong, K.S. (2001) Study of the Relationship between Corporate Governance Structure and the Extent of Voluntary Disclosure. Journal of International Accounting, Auditing and Taxation, 10, 139-156. http://www.sciencedirect.com/science/article/pii/S1061951801000416 http://dx.doi.org/10.1016/S1061-9518(01)00041-6 
[19] Hoitash, U., Hoitash, R. and Bedard, J.C. (2009) Corporate Governance and Internal Control over Financial Reporting: A Comparison of Regulatory Regions. The Accounting Review, 2, 124-128.

http://aaajournals.org/doi/abs/10.2308/accr.2009.84.3.839

http://dx.doi.org/10.2308/accr.2009.84.3.839

[20] Watts, R. and Zimmerman, J. (1983) Agency Problems, Auditing, and the Theory of the Firm: Some Evidence. Journal of Law and Economics, 2, 613-633.

http://www.researchgate.net/profile/Ross_Watts/publication/24100630_Agency_Problems_Auditing_and_the_Theory_ of_the_Firm_Some_Evidence/links/0912f50dcb6e398a51000000.pdf

http://dx.doi.org/10.1086/467051 